\title{
Wpływ uwarunkowań genetycznych i czynników środowiskowych na zachorowalność na cukrzycę typu 2
}

\section{The influence of genetics and environment al factors and the incidence of type 2 diabetes}

\section{NATALIA CECOT ${ }^{1}$ \\ BEATA BORUCZKOWSKA2}

${ }^{1}$ Instytut Nauk o Zdrowiu, Państwowa Uczelnia Zawodowa we Włocławku, Wojewódzki Szpital Specjalistyczny we Włocławku, Oddział Chorób Wewnętrznych i Nefrologii

2 Centrum Diagnostyczno-Lecznicze Barska we Włocławku

DOI: http://dx.doi.org/10.21784/IwP.2020.015

ISSN: 2451-1846

\section{Streszczenie}

Wstęp. Cukrzyca jest przewlekłą chorobą metaboliczną wynikająca z zaburzonego wydzielania lub działania insuliny - hormonu produkowanego przez trzustkę. Jest ona uwarunkowana genetycznie-wielogenowo oraz poprzez czynniki środowiskowe, głównie otyłość, złe nawyki żywieniowe oraz brak aktywności fizycznej.

Cel. Celem niniejszej pracy była ocena wpływu uwarunkowań genetycznych i czynników środowiskowych na zachorowalność na cukrzycę typu 2. 
Materiał i metody. W niniejszej pracy wykorzystano technikę ankietowania oraz klasyczną jakościową analizę dokumentów. Narzędzia badawcze służą technicznemu gromadzeniu danych i są nimi np.: kwestionariusz ankiety. W badaniu wzięli udział pacjenci Poradni Diabetologicznej CDL Barska we Włocławku. Warunkiem była pisemna zgoda pacjenta. Ankietę otrzymali pacjenci i przeprowadzono ją za ich zgodą.

Wyniki. Jednym z czynników powodujących powikłania jest spożywanie alkoholu. Najwięcej badanych stwierdziło, że nie spożywa alkoholu (45\%), ale bardzo duża część badanych przyznała, iż spożywa alkohol okazjonalnie (44\%). Pacjenci wskazali, że alkohol może wywołać niedocukrzenie (51\%). Najwięcej osób odpowiedziało, że alkohol źle wpływa na leczenie cukrzycy typu 2 (88\%).

Wskazując na rodzaj aktywności fizycznej badani najczęściej podawali spacery $(48,4 \%)$ oraz jazdę na rowerze $(25,8 \%)$. Pacjenci przyznali, iż aktywność fizyczną uprawiają raz w tygodniu (34\%) lub nie uprawiają wcale (27\%).

Wnioski. Czynniki genetyczne i środowiskowe w zachorowalności cukrzycy typu 2 odgrywają bardzo ważną rolę.

Słowa kluczowe: uwarunkowania genetyczne, czynniki środowiskowe, cukrzyca typu 2.

\section{Summary:}

Admission. Diabetes mellitus is a chronic metabolic disease resulting from disturbed secretion or action of insulin, a hormone produced by the pancreas. It is genetically and multi-gene conditioned and by environmental factors, mainly obesity, bad eating habits and lack of physical activity.

Aim. The aim of this study was to assess the influence of genetic conditions and environmental factors on the incidence of type 2 diabetes.

Material and methods. In this work, the survey technique and classic qualitative analysis of documents were used. Research tools are used for the technical collection of data, such as: interview questionnaire, observation sheet, dictaphone, pen, etc. Patients from the CDL Barska Diabetes Clinic in Włocławek participated in the study. The condition was the patient's written 
consent. Patients received the questionnaire and it was conducted with their consent

Results. One of the factors causing complications is alcohol consumption. Most respondents stated that they do not consume alcohol (45\%), but a very large proportion of the respondents admitted that they drink alcohol occasionally (44\%). Patients indicated that alcohol may induce hypoglycaemia (51\%). Most of the respondents answered that alcohol is bad for the treatment of type 2 diabetes (88\%).

When indicating the type of physical activity, the respondents most often reported walking $(48,4 \%)$ and cycling $(25,8 \%)$. Patients admitted that they do physical activity once a week (34\%) or not at all (27\%).

Conclusions. Genetic and environmental factors in the incidence of type $2 \mathrm{di}$ abetes are playing the very important role.

Keywords: genetics, environmental factors, type 2 diabetes

\section{Wstęp}

Cukrzyca należy do grupy chorób metabolicznych, która charakteryzuje się hiperglikemią wynikającą z defektu produkcji lub działania insuliny wydzielanej przez trzustkę. Długotrwale utrzymująca się hiperglikemia powoduje uszkodzenie, zaburzenia czynności i niewydolność różnych narządów, w szczególności oczu, nerek, nerwów, serca i naczyń krwionośnych [1].

Wiadomo, że cukrzyca typu 2 jest chorobą dziedziczną choć jej etiologia nie jest do końca znana. W jej patogenezie biorą udział dwa czynniki: genetyczne i środowiskowe. Dziedziczy się skłonność do rozwoju choroby. Jej wystąpieniu sprzyja otyłość, która jest przyczyną insulinooporności [2].

Cukrzycę typu 2 nazywano kiedyś cukrzycą starczą, ponieważ dotyczyła głownie osób starszych. Ze względu na panującą epidemię otyłości, wiek zachorowania na tę chorobą znacznie się obniżył. Obecnie 
występuje ona coraz częściej u otyłych osób w młodszym wieku, niekiedy nawet u nastolatków [3].

Z biegiem czasu obserwuje się stały wzrost liczby nowych przypadków zapadalności na cukrzycę typu 2. Przyczyną tego jest ogólny wzrost populacji na świecie, starzenie się społeczeństwa, urbanizacja, brak aktywności fizycznej i otyłość. Stanowi to poważny problem zdrowotny i społeczny [4].

Czynniki genetyczne w zachorowalności cukrzycy typu 2 odgrywają bardzo ważną rolę. Mechanizm molekularny występowania predyspozycji rodzinnej nie został jeszcze dokładnie poznany. Uważa się, że jest to dziedziczenie poligenowe. Wykazano, że ryzyko wystąpienia hiperglikemii u krewnych I stopnia osób chorych na cukrzycę typu 2 jest 4-krotnie wyższy niż w populacji ogólnej. Cukrzyca typu 2 jest uwarunkowana genetycznie-wielogenowo tzn. jest rezultatem mutacji w wielu genach [5].

Czynniki środowiskowe są główną przyczyną wzrastającej częstości występowania populacji cukrzycy typu 2. Należą do nich m.in.:

- Otyłość - to ogromne zagrożenie dla zdrowia i życia. Otyli ludzie żyją 8-10 lat krócej aniżeli osoby z prawidłową masą ciała. Częściej również chorują na cukrzycę. Ponad $80 \%$ chorych na cukrzycę typu 2 ma nadwagę. Stwierdzono, że przyrost masy ciała o $20 \mathrm{~kg}$ zwiększa piętnastokrotnie ryzyko zapadalności na tę chorobę, zaś ubytek 20 kg niemal całkowicie znosi to ryzyko. Zaobserwowano, że otyłość u dzieci powoduje występowanie u nich cukrzycy typu $2[6,7,8]$.

- Aktywność fizyczna - zakwalifikowana jako niefarmakologiczna metoda leczenia. Każdy wzrost wydatku energetycznego o $500 \mathrm{kcal}$ tygodniowo zmniejsza ryzyko zapadalności na cukrzycę o 6\% [6,7].

- Nieprawidłowy sposób odżywiania się - cukrzyca to choroba przemiany materii co oznacza, że energia przyjęta w postaci pokarmu nie jest właściwie wykorzystywana przez organizm. Trwała zmiana nawyków żywieniowych to podstawowa metoda skutecznego 
leczenia. Celem leczenia żywieniowego pacjentów jest utrzymanie optymalnej glikemii, stężenia lipidów w surowicy oraz optymalnego ciśnienia tętniczego i uzyskanie pożądanej masy ciała [6,7].

\section{Cel}

Celem pracy była ocena wpływu uwarunkowań genetycznych i czynników środowiskowych na zachorowalność na cukrzycę typu 2.

\section{Materiał i metody}

W niniejszej pracy wykorzystano metodę sondażu diagnostycznego, technikę ankietowania oraz klasyczną jakościową analizę dokumentów. Narzędzia badawcze służą technicznemu gromadzeniu danych i był nim kwestionariusz ankiety. $W$ badaniu wzięli udział pacjenci Poradni Diabetologicznej CDL Barska we Włocławku. Warunkiem była pisemna zgoda pacjenta. Ankietę otrzymali pacjenci i przeprowadzono ją za ich zgodą.

\section{Wyniki}

Tab. 1. Wystąpienie zachorowań na cukrzycę w rodzinie.

\begin{tabular}{|l|c|c|}
\hline \multicolumn{1}{|c|}{ Odpowiedź } & Liczba & $\%$ \\
\hline Tak, na cukrzycę typu 2 & 39 & 39,0 \\
\hline Tak, na cukrzycę typu 1 & 2 & 2,0 \\
\hline Tak, na cukrzycę typu 1 i 2 & 1 & 1,0 \\
\hline Nie & 58 & 58,0 \\
\hline Razem & 100 & 100,0 \\
\hline
\end{tabular}




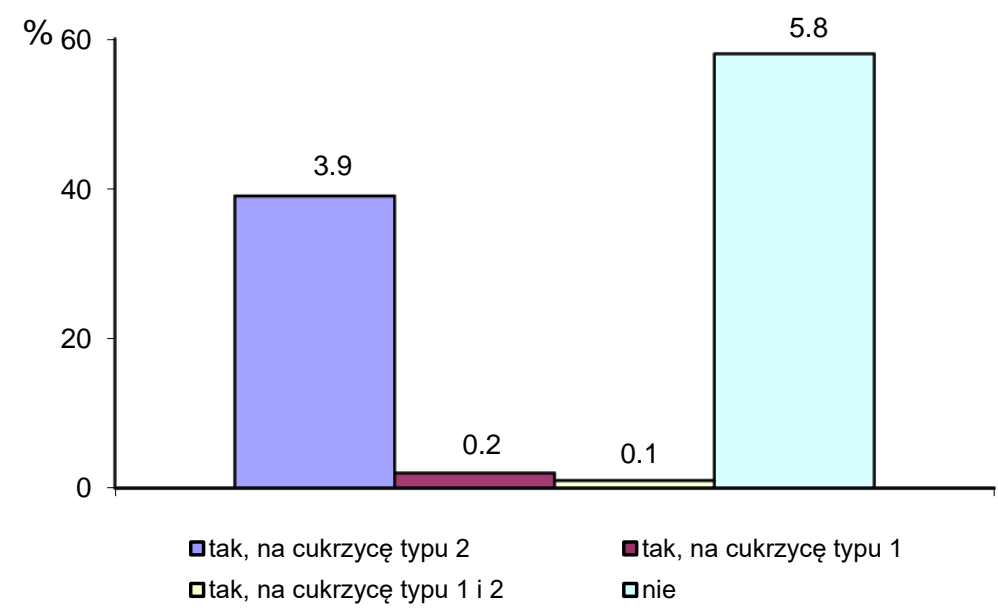

Ryc. 1 Wystąpienie zachorowań na cukrzycę w rodzinie.

Najwięcej badanych wskazało, że w rodzinie nikt nie chorował na cukrzycę - 58,0\%. Najmniej wskazało, że na cukrzycę typu 1 i 2-1,0\%.

Tab. 2 Dzienna ilość spożywanych posiłków.

\begin{tabular}{|l|c|c|}
\hline \multicolumn{1}{|c|}{ Odpowiedź } & Liczba & $\%$ \\
\hline Mniej niż trzy & 6 & 6,0 \\
\hline Trzy & 21 & 21,0 \\
\hline Cztery & 34 & 34,0 \\
\hline Pięć & 37 & 37,0 \\
\hline Więcej niż pięć & 2 & 2,0 \\
\hline Razem & 100 & 100,0 \\
\hline
\end{tabular}




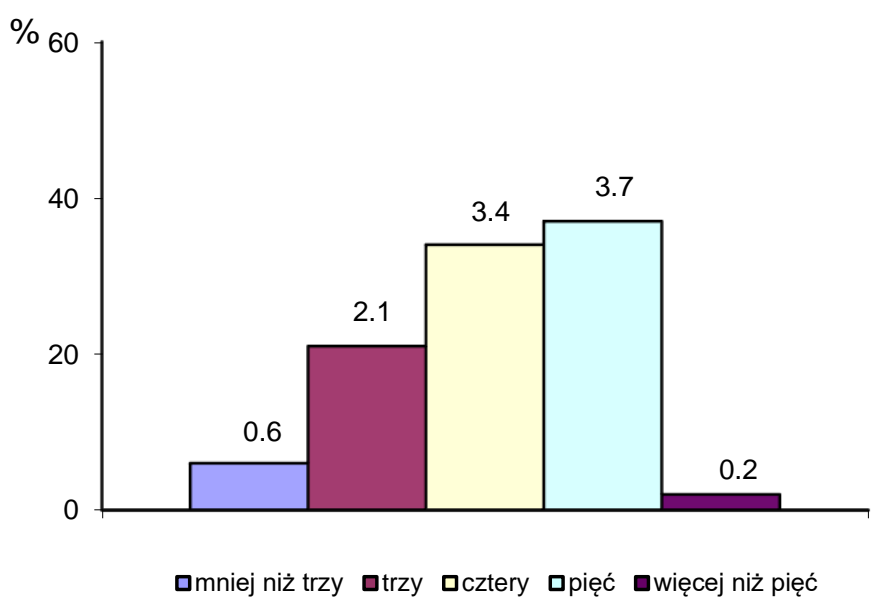

Ryc. 2 Dzienna ilość spożywanych posiłków.

Najwięcej badanych stwierdziło, że dziennie spożywa pięć posiłków - 37,0\% lub cztery - 34,0\%, najmniej wskazało, że więcej niż pięć - 2,0\%.

Tab. 3 Czas trwania przerwy między posiłkami.

\begin{tabular}{|l|c|c|}
\hline \multicolumn{1}{|c|}{ Odpowiedź } & Liczba & $\%$ \\
\hline 1 godzinę & 1 & 1,0 \\
\hline 2-3 godziny & 43 & 43,0 \\
\hline 4-5 godzin & 38 & 38,0 \\
\hline$>5$ godzin & 7 & 7,0 \\
\hline Nie jem regularnie & 11 & 11,0 \\
\hline Razem & 100 & 100,0 \\
\hline
\end{tabular}




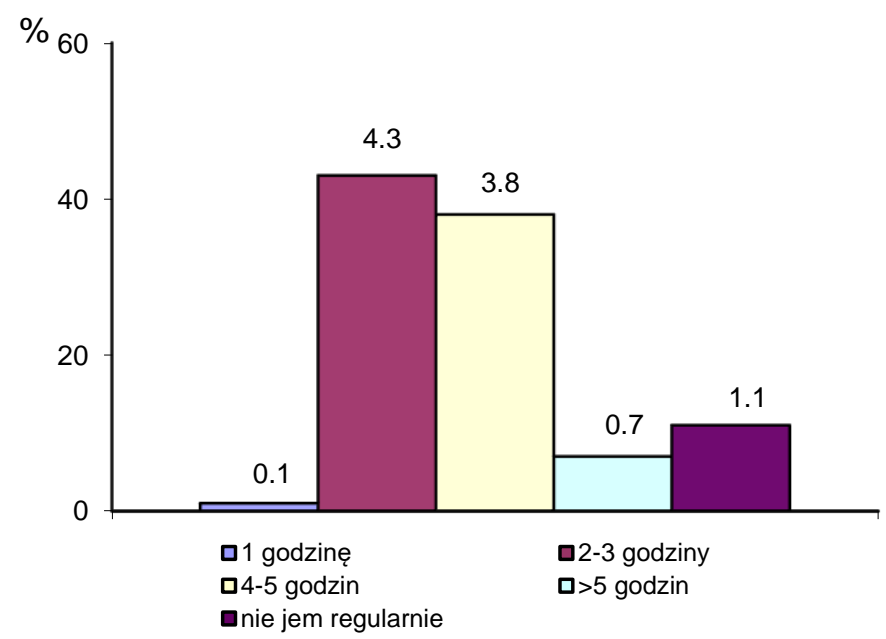

Ryc. 3 Czas trwania przerwy między posiłkami.

Najwięcej badanych stwierdziło, że przerwa między posiłkami trwa 2-3 godzin - 43,0\% lub 4-5 godzin - 38,0\%, najmniej wskazało, że 1 godzinę - 1,0\%.

Tab. 4 Wpływ spożycia alkoholu na poziom cukru we krwi.

\begin{tabular}{|l|c|c|}
\hline \multicolumn{1}{|c|}{ Odpowiedź } & Liczba & $\%$ \\
\hline Nie ma żadnego & 8 & 8,0 \\
\hline $\begin{array}{l}\text { Może wywołać nie- } \\
\text { docukrzenie }\end{array}$ & 51 & 51,0 \\
\hline $\begin{array}{l}\text { Podnosi poziom glu- } \\
\text { kozy we krwi }\end{array}$ & 14 & 14,0 \\
\hline Nie wiem & 27 & 27,0 \\
\hline Razem & 100 & 100,0 \\
\hline
\end{tabular}




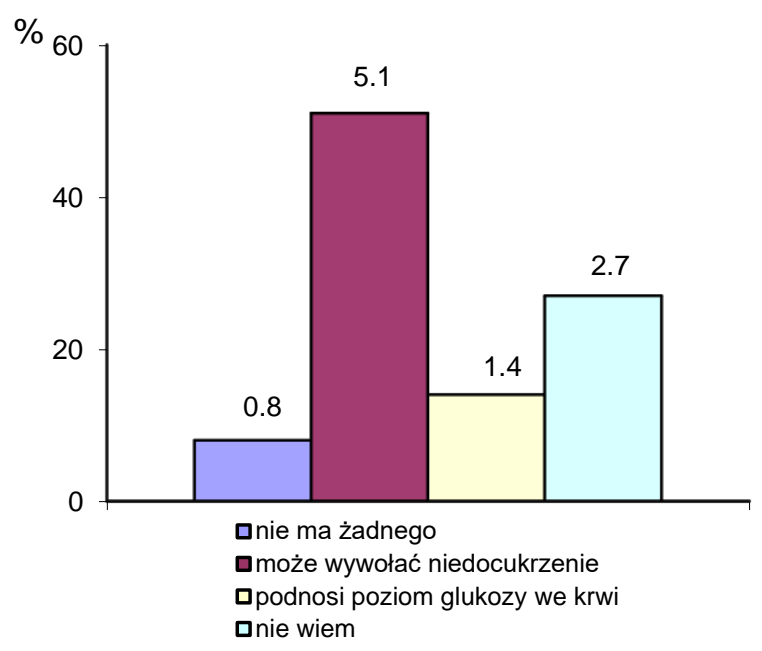

Ryc. 4 Wpływ spożycia alkoholu na poziom cukru we krwi.

Najwięcej badanych wskazało, że alkohol może wywołać niedocukrzenie - 51,0\%, najmniej wskazało, że nie ma żadnego wpływu na poziom cukru we krwi - 8,0\%.

Tab.5 Rodzaj aktywności fizycznej.

\begin{tabular}{|l|c|c|}
\hline \multicolumn{1}{|c|}{ Odpowiedź } & Liczba & $\%$ \\
\hline Jazda na rowerze & 24 & 25,8 \\
\hline Basen & 13 & 14,0 \\
\hline Spacery & 45 & 48,4 \\
\hline Nordic walking & 10 & 10,8 \\
\hline Inne & 1 & 1,1 \\
\hline Razem & 100 & 100,0 \\
\hline
\end{tabular}




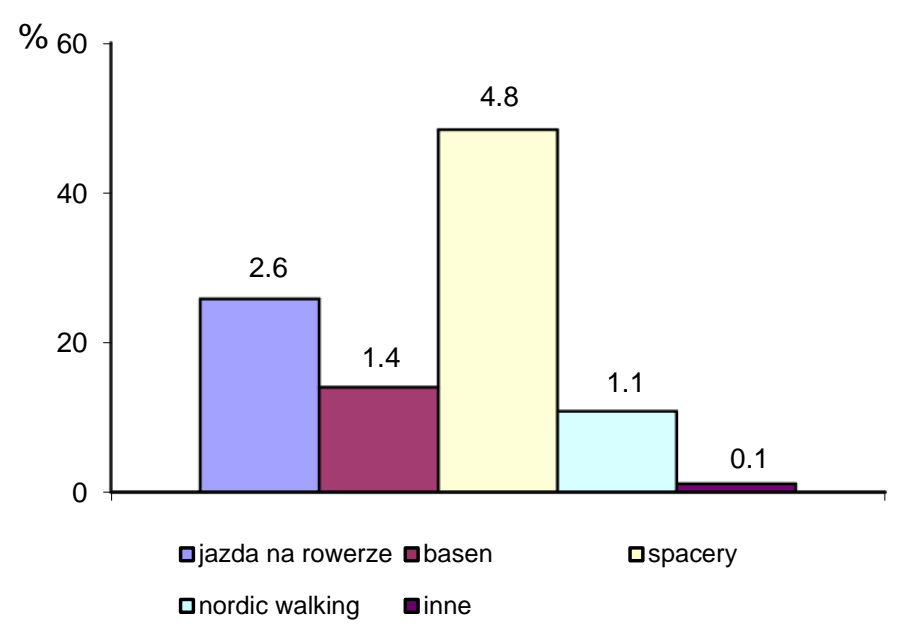

Ryc.5 Rodzaj aktywności fizycznej.

Wskazując na rodzaj aktywności fizycznej badani zaznaczali po kilka stwierdzeń. Łącznie od 80 osób odnotowano 93 odpowiedzi. Najwięcej wskazało na spacery - 45 osób, co stanowiło 48,4\% wszystkich odpowiedzi oraz na jazdę na rowerze - 24 osoby $(25,8 \%)$. Najmniej wskazało na „inny” niż określony rodzaj - 1 osoba $(1,1 \%)$. Na jeden rodzaj wskazało - 71 osób, na dwa rodzaje - 7 osób oraz na trzy rodzaje -2 osoby.

Tab. 6 Częstość uprawiania aktywności fizycznej.

\begin{tabular}{|l|c|c|}
\hline \multicolumn{1}{|c|}{ Odpowiedź } & Liczba & $\%$ \\
\hline Raz w tygodniu & 34 & 34,0 \\
\hline 2-3 razy w tygodniu & 24 & 24,0 \\
\hline Częściej & 15 & 15,0 \\
\hline Wcale & 27 & 27,0 \\
\hline Razem & 100 & 100,0 \\
\hline
\end{tabular}




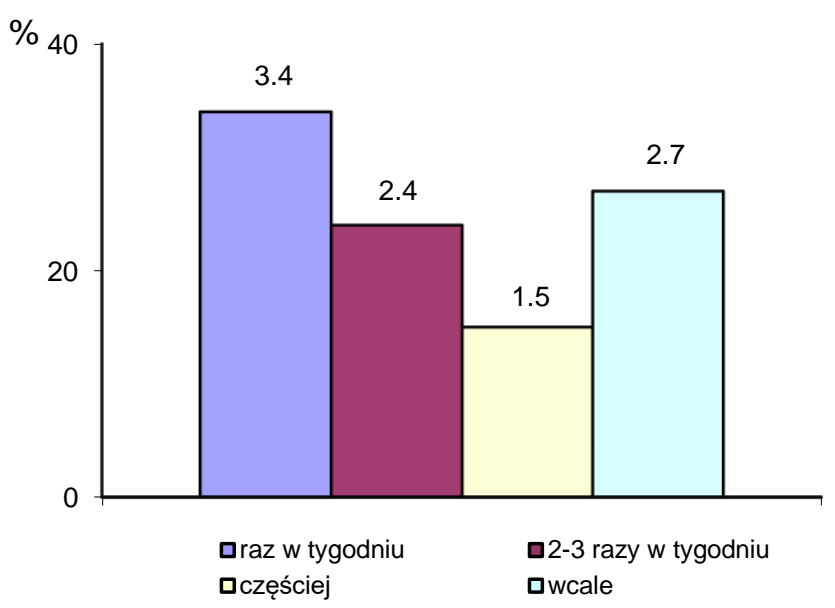

Ryc. 6 Częstość uprawiania aktywności fizycznej.

Najwięcej badanych wskazało, że uprawia aktywność fizyczną raz w tygodniu - 34,0\% lub nie uprawia wcale - 27,0\%, najmniej wskazało, że częściej niż 2-3 razy w tygodniu - 15,0\%.

\section{Dyskusja}

Cukrzyca to choroba, której nie można całkowicie wyleczyć, ale przy odpowiednim stylu życia i przestrzeganiu diety oraz możliwe jest utrzymanie chorego w dobrym stanie ogólnym [8].

Występowanie rodzinne cukrzycy potwierdza $42 \%$ badanych. Najwięcej osób odpowiedziało, że do diabetologa uczęszcza 2 razy w roku (43\%). Pacjenci podają, że edukacja chorych na cukrzycę jest ważna (95\%). U większości nikt w rodzinie nie chorował (58\%), a zdecydowana większość uważa, iż wczesne wykrycie cukrzycy typu 2 jest ważne $(97 \%)$. 
Według Kokockiej, Bartoszek, Ślusarskiej i Kuryły analizując czas trwania choroby można stwierdzić, iż najwięcej badanych chorowało na cukrzycę typu 2 od 1 do 5 lat. W grupie tej powikłania cukrzycy typu 2 zdiagnozowano u ponad $80 \%$ badanych. Powyższe badanie wykazuje, że nawet krótki okres trwania choroby pogarsza stan kliniczny [9].

Jednym z czynników powodujących powikłania jest spożywanie alkoholu. Najwięcej badanych stwierdziło, że nie spożywa alkoholu (45\%), ale bardzo duża część badanych przyznała, iż spożywa alkohol okazjonalnie (44\%). Pacjenci wskazali, że alkohol może wywołać niedocukrzenie (51\%). Najwięcej osób odpowiedziało, że alkohol źle wpływa na leczenie cukrzycy typu 2 (88\%).

Według Orywal, Jelskiego i Szmitkowskiego zależność między przemianą węglowodanową, a spożywaniem alkoholu metylowego powoduje ostre powikłanie hipoglikemię, ale także ma swój udział w patogenezie wielu chorób trzustki, zaburzających zarówno endokrynną jak i egzokrynną funkcję tego narządu [10] .

Wskazując na rodzaj aktywności fizycznej badani najczęściej podawali spacery $(48,4 \%)$ oraz jazdę na rowerze $(25,8 \%)$. Pacjenci przyznali, iż aktywność fizyczną uprawiają raz w tygodniu (34\%) lub nie uprawiają wcale (27\%).

Dla porównania według Mędrela-Kuder i Bis większość kobiet i mężczyzn deklarowała bierny sposób spędzania wolnego czasu. Aktywność ruchową deklarowało 23\% kobiet i 30\% mężczyzn (spacery 85\% pacjentek i 75\% pacjentów). Zdecydowana większość (75\% kobiet i 63\% mężczyzn) deklarowała brak aktywności fizycznej [11] . 


\section{Wnioski}

Na podstawie uzyskanych wyników sformułowano następujące wnioski:

1. Występowanie rodzinne cukrzycy potwierdza $42 \%$ badanych.

2. W badanej grupie pozytywne zachowania żywieniowe dotyczą liczby posiłków, negatywne to niesystematyczne przyjmowanie posiłków.

3. Badani pacjenci znają wpływ alkoholu na poziom glukozy we krwi.

4. Najczęściej wybieraną aktywnością fizyczną są spacery, najczęściej z częstotliwością 1 raz w tygodniu.

\section{Zalecenia dla praktyki pielęgniarskiej}

Podsumowując niniejszą pracę istotne znaczenie w cukrzycy mają czynniki, które przyspieszają jej rozwój. Należą do nich: nieodpowiedni styl życia, mała aktywność fizyczna, spożywanie używek i brak samokontroli. W edukacji pacjenta i profilaktyce pielęgniarka powinna uwzględnić je jako zasadnicze elementy.

\section{Bibliografia/Bibliography:}

1. Kurowska K., Toś M. Poczucie własnej skuteczności a zachowania zdrowotne w grupie osób z rozpoznaniem cukrzycy typu 2, Polski Przegląd Nauk o Zdrowiu 2017; 1 (50):31-37.

2. Karpińska A., Łopatka P. A., Rossa S., Cwajda-Białasik J., Szewczk M. T. Znaczenie Fizjoterapii w prewencji i leczeniu cukrzycy typu 2, z uwzględnieniem zespołu stopy cukrzycowej, Pielęgniarstwo Chirurgiczne i Angiologiczne $2018 ; 2: 39-43$.

3. Szewczyk A. Pielęgniarstwo Diabetologiczne. PZWL, Warszawa 2014. 
4. Kołpa M., Grochowska A., Kubik B., Stradomska K. Styl życia i wyrównanie metaboliczne u pacjentów z cukrzycą typu 2, a ryzyko powikłań przewlekłych tej choroby. Diabetologia Praktyczna 2018,4,3:162-170.

5. Bronisz A., Rotkiewicz K., Głuch E., Pilaczyńska-Cemel M., Słonina A., Bronisz M., Jaraczewska J., Radziejewska A., Ruszkiewicz A., Junik R. Występowanie czynników ryzyka cukrzycy typu 2 u krewnych chorych. Diabetologia Praktyczna 2008, tom 9 nr 2.

6. Sieradzki J.(red.) Cukrzyca. Via Medica, Gdańsk 2015.

7. www.apteline.pl/artykuly/znaczenie-aktywnosci-fizycznej-w-leczeniucukrzycy-typu-2, (dostęp: 12.05.2020 r.).

8. Jankowska-Polańska B., Uchmanowicz I., Bober A. Wpływ edukacji na jakość życia chorych z cukrzycą typu 2. Współczesne Pielęgniarstwo i Ochrona Zdrowia, 2013;2,1:7-11.

9. Kokocka K., Bartoszek A., Ślusarska B., Curyła I., Sposób leczenia, czas trwania choroby oraz powikłania cukrzycy typu 2 a jakość życia osób chorych. Medycyna Rodzinna 2017;1:9-16.

10. Orywal K., Jelski W., Szmitkowski M., Udział alkoholu etylowego w powstawaniu zaburzeń metabolizmu węglowodanów. X Międzynarodowy Kongres Polskiego Towarzystwa Alergologicznego, Bydgoszcz 7-10 października 2009.

11. Mędrela-Kuder E., Bis H. Porównanie aktywności fizycznej i diety u kobiet i mężczyzn chorych na cukrzycę typu 2. Medycyna Ogólna i Nauki o Zdrowiu, 2014; 20,1:31-33. 